\title{
Modeling the individual growth of the Gulf corvina, Cynoscion othonopterus (Pisces: Sciaenidae), using a multi-model approach
}

\section{Modelando el crecimiento individual de la corvina golfina, Cynoscion othonopterus (Pisces: Sciaenidae), con el enfoque multimodelo}

\author{
E Alberto Aragón-Noriega \\ Centro de Investigaciones Biológicas del Noroeste, Unidad Sonora, Km 2.35 Camino al Tular, \\ Estero Bacochibampo, Guaymas, Sonora 85454, México. E-mail: aaragon04@cibnor.mx
}

\begin{abstract}
The Gulf corvina, Cynoscion othonopterus, is an endemic sciaenid of the Upper Gulf of California and Colorado River Delta biosphere reserve. It is a high-value fishery resource in this region. To sustainably manage this resource, it is necessary to address its individual growth pattern. Previous studies on C. othonopterus growth have fitted the von Bertalanffy growth model (VBGM) without examining alternative models. In this study, the main objective was to analyze the individual growth of the Gulf corvina via a multi-model inference (MMI) approach rather than simply applying the VBGM. Five growth models-VBGM, logistic, Gompertz, Schnute, and Schnute-Richards - were tested. The parameters of each model and their confidence intervals (CI) were computed using the maximumlikelihood method. The MMI was used to average the asymptotic length $\left(L_{\infty}\right)$. The best-fitting model was selected using the Akaike information criterion, and the Schnute-Richards growth model best described the growth of the Gulf corvina. The $L_{\infty}$ values obtained via MMI averaged $735.0 \mathrm{~mm}$ (95\% CI: 730.4-739.5 mm). The conclusion is that the growth of C. othonopterus exhibits a biphasic pattern that is better described by a higher-parameter model such as the Schnute-Richards model.
\end{abstract}

Key words: growth, multi-model inference, Akaike information criterion, Upper Gulf of California, Cynoscion othonopterus.

RESUMEN. La corvina golfina, Cynoscion othonopterus, es un pez scianido endémico de la reserva de la biosfera del Alto Golfo de California y Delta del Río Colorado. Es un recurso pesquero de alto valor económico para la región. Para el manejo sostenible de este recurso, es necesario conocer su patrón de crecimiento individual. Los estudios previos sobre el crecimiento de C. othonopterus sólo han utilizado el modelo de crecimiento de von Bertalanfy (MCVB) sin probar modelos alternativos. En este estudio, el objetivo principal fue analizar el crecimiento individual de la corvina golfina mediante un enfoque de inferencia multimodelo (IM) en vez de simplemente aplicar el MCVB. Se pusieron a prueba cinco modelos-MCVB, logístico, Gompertz, Schnute y Schnute-Richards. Los parámetros de cada modelo y sus respectivos intervalos de confianza (IC) fueron calculados usando el método de máxima verosimilitud. La IM fue usada para determinar la longitud asintótica $\left(L_{\infty}\right)$ promedio. Se seleccionó el mejor modelo usando el criterio de información de Akaike, y el modelo de crecimiento Schnute-Richards fue el que mejor describió el crecimiento individual de la corvina golfina. El valor promedio de $L_{\infty}$, obtenida con la IM, fue de $735.0 \mathrm{~mm}$ (95\% IC: 730.4-739.5 mm). Se concluye que crecimiento de $C$. othonopterus exhibe un patrón de crecimiento bifásico que es mejor descrito por un modelo con mayor cantidad de parámetros, como el de Schnute-Richards.

Palabras clave: crecimiento, inferencia multi-modelo, criterio de información de Akaike, Alto Golfo de California, Cynoscion othonopterus.

\section{INTRODUCTION}

The Gulf corvina, Cynoscion othonopterus (Jordan and Gilbert 1882), is endemic to the Upper Gulf of California (UGC) (fig. 1). The Sciaenidae family comprises the fishes commonly known as drums or croakers (Chao 1995). The Gulf corvina can reach a total length of $920 \mathrm{~mm}$ and live for at least 9 years (Román-Rodríguez 2000). Adults are carnivorous, feeding on benthic crustaceans such as shrimp and crabs, mollusks such as octopus and squid, and schooling fishes such as sardine and anchovies (Román-Rodríguez 2000). This species exhibits fidelity to spawning site and season and is considered an aggregate spawning species (Sadovy and Erisman 2012). Spawning aggregations of adult Gulf

\section{INTRODUCCIÓN}

La corvina golfina, Cynoscion othonopterus (Jordan y Gilbert 1882), es endémica del Alto Golfo de California (AGC) (fig. 1). La familia Sciaenidae comprende a los peces comúnmente conocidos como, corvinas, curvinas, verrugatos y roncadores o roncachos (Chao 1995). La corvina golfina puede alcanzar una longitud total de $920 \mathrm{~mm}$ y vivir por lo menos 9 años (Román-Rodríguez 2000). Los adultos son carnívoros y se alimentan de crustáceos bentónicos como camarones y jaibas, moluscos como pulpos y calamares, y peces pelágicos formadores de cardúmenes como sardinas y anchovetas (Román-Rodríguez 2000). Esta especie presenta fidelidad al sitio y a la temporada de desove, y se considera 


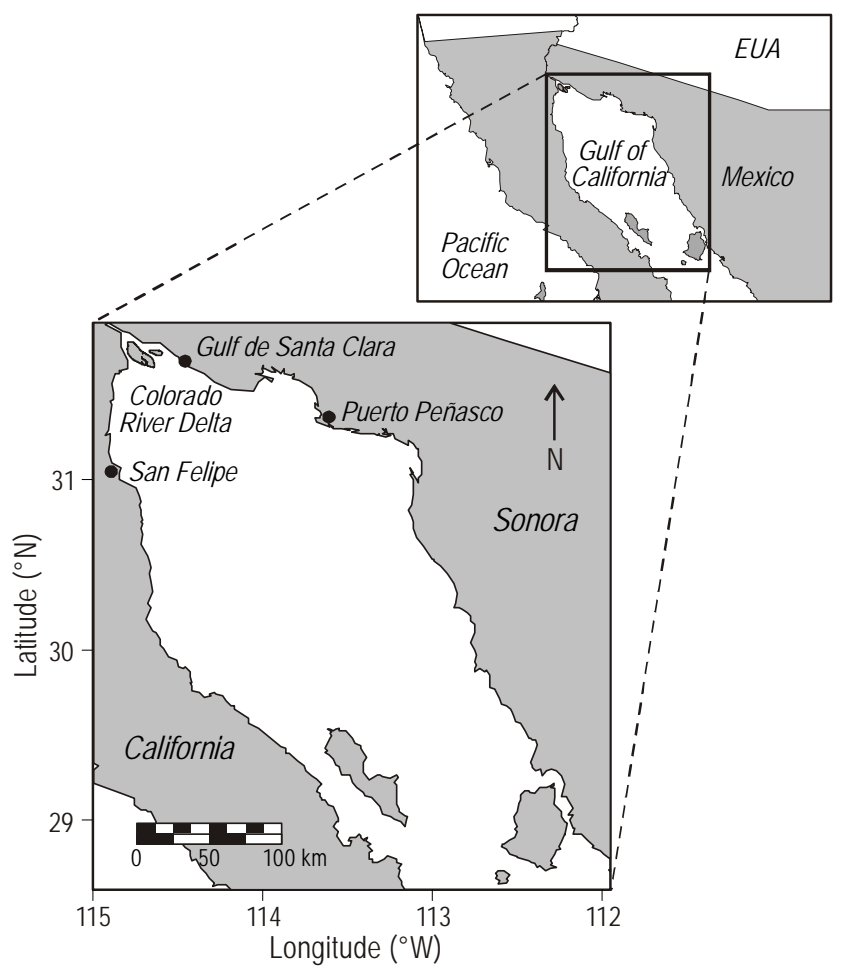

Figure 1. Geographic range of Gulf corvina, Cynoscion othonopterus, and locations of the main fishing communities.

Figura 1. Distribución geográfica de la corvina golfina, Cynoscion othonopterus, y ubicación de las principales comunidades pesqueras.

corvina form near the mouth of the Colorado River Delta (CRD) from February to May each year (Román-Rodríguez 2000, Erisman et al. 2012, Sadovy and Erisman 2012). This species is gonochoric (separate sexes), oviparous (eggs develop outside of the body), and iteroparous (produces offspring in successive seasonal and annual batches).

The fishery for Gulf corvina is restricted exclusively to the UGC and CRD when species travel there for the spawning aggregation. There is some evidence that a commercial fishery for Gulf corvina existed from 1917 to 1940 (RománRodríguez 2000) but collapsed in the early 1960s. This collapse was attributed to fishing practices and the reduction in flow of the Colorado River into the Gulf of California, which reduced available nursery habitat for juveniles (RománRodríguez 2000, Rowell et al. 2005, Rowell et al. 2008). Official records indicate that the Gulf corvina fishery reappeared during the 1990s and peaked in 2002 at $4300 \mathrm{t}$. Since that time, production has fluctuated between 1500 and $3700 \mathrm{t}$. Fishing occurs primarily during the spring tides from February to May, when the species migrates into the area to form aggregations and spawns in the estuaries a week before the new and full moon from late February to early May each year (Acosta-Valenzuela 2010, Sadovy and Erisman 2012). The Gulf corvina fishery currently ranks below only the dentro de las especies que forman agregaciones reproductivas (Sadovy y Erisman 2012). Las agregaciones reproductivas de los adultos de corvina golfina se presentan en la boca del delta del río Colorado (DRC) de febrero a mayo de cada año (Román-Rodríguez 2000, Erisman et al. 2012, Sadovy y Erisman 2012). Cynoscion othonopterus es una especie gonocórica (sexos separados), ovípara (los huevos se desarrollan fuera del cuerpo del organismo) e iterópara (produce crías en sucesivos períodos anuales y estacionales).

La pesquería de la corvina golfina se restringe a las zonas del AGC y DRC cuando la especie realiza sus migraciones reproductivas y forma los agrupamientos reproductivos. Existe evidencia de que la pesquería comercial de corvina golfina existió de 1917 a 1940 (Román-Rodríguez 2000) pero colapsó a principios de los años sesenta del siglo pasado. Este colapso fue atribuido a los efectos de la pesca y a la reducción del flujo del río Colorado hacia el golfo de California, ya que con esto se redujo el hábitat de crianza de los peces jóvenes (Román-Rodríguez 2000, Rowell et al. 2005, Rowell et al. 2008). Los registros pesqueros oficiales indican que la pesquería de corvina golfina reapareció a principios de 1990 y tuvo un máximo de capturas en 2002 con 4300 t. Desde ese año, las capturas han fluctuado entre 1500 y 3700 t. La pesca se realiza principalmente una semana antes de la luna nueva y la luna llena, desde finales de febrero hasta principios de mayo de cada año, cuando la especie migra al área para formar agregaciones y desovar en los estuarios (AcostaValenzuela 2010, Sadovy y Erisman 2012). La pesquería de corvina golfina sólo está por debajo de la pesquería de camarón en cuanto al rango de pesquerías más productivas del AGC (Rodríguez-Quiroz et al. 2010). La mayoría de los pescadores de la región capturan ambos recursos y alternan el esfuerzo pesquero en relación con las medidas regulatorias (e.g., vedas), la demanda del mercado y la variación estacional de abundancia de cada especie.

Un manejo pesquero efectivo requiere de evaluaciones de poblaciones detalladas y una comprensión de la dinámica poblacional de la especie sujeta a explotación. Por esa razón, el análisis de los parámetros de crecimiento individual son indispensables. El modelo más popular y más comúnmente utilizado es del modelo de crecimiento de von Bertalanffy (MCVB). A pesar de que Katsanevakis y Maravelias (2008) demostraron que la inferencia multimodelo es una mejor alternativa que el simple uso del MCVB y de que otros autores también han usado el enfoque de la inferencia multimodelo (Zhu et al. 2009, Alp et al. 2011, Baer et al. 2011), el uso del MCVB como única alternativa es todavía ampliamente utilizado en los estudios de crecimiento de peces (Powers et al. 2012, Gherard et al. 2013, Hadj-Taieb et al. 2013). Las alternativas más comunes al MCVB son el modelo de crecimiento de Gompertz, el modelo logístico (Ricker 1975), el modelo de Schnute (Schnute 1981) y el modelo de Schnute-Richards (Schnute y Richards 1990). Cuando se utiliza más de un modelo, generalmente la selección del mejor modelo se basa en la forma de la curva 
shrimp fishery in terms of the most productive fisheries of the UGC (Rodríguez-Quiroz et al. 2010). Most commercial fishers in the region target both species and alter their efforts seasonally in relation to fisheries regulations (e.g., closures), market demands, and the seasonal abundance of each species.

Effective fisheries management requires a detailed understanding of stock assessment and population dynamics. For this purpose, an analysis of individual growth parameters is a requisite. The most popular and commonly applied model among all individual growth models is the von Bertalanffy growth model (VBGM). The multi-model inference approach has proven to be a better alternative than VBGM (Katsanevakis and Maravelias 2008) and has been used by other authors (Zhu et al. 2009, Alp et al. 2011, Baer et al. 2011). Nevertheless, VBGM is still widely used for fish growth studies (Powers et al. 2012, Gherard et al. 2013, Hadj-Taieb et al. 2013). The most common alternatives to the generalized VBGM are the Gompertz growth model, the logistic model (Ricker 1975), the Schnute model (Schnute 1981), and the Schnute-Richards model (Schnute and Richards 1990). When more than one model is used, model selection is usually based on the shape of the anticipated curve, the biological assumptions, and the fit to the data (Zhu et al. 2009). Parameter inference and estimation and the precision of these estimates are based solely on the fitted model. Another approach to choosing the best model is based on information theory. This approach has been recommended as a more robust alternative compared to traditional approaches (Katsanevakis 2006). The most common informationtheoretic approach is to use the Akaike information criterion (AIC) (Katsanevakis 2006, Cruz-Vásquez et al. 2012).

Previous studies (Román-Rodríguez 2000, Erisman et al. 2009, Erisman 2012) that have reported on C. othonopterus growth have all used the VBGM; for that reason, the objective of the present study was to determine the growth parameters of the Gulf corvina in the UGC using a multi-model approach and to evaluate the utility of averaged versus raw data for computing the growth parameters.

\section{MATERIALS AND METHODS}

\section{Data source}

Data were obtained from the CONABIO data base (SNIB-CONABIO; http://www.conabio.gob.mx/institucion/ cgi-bin/datos.cgi? Letras $=$ L\&Numero $=298$ ), specifically from the ecological data 4 spreadsheet (Román-Rodríguez 2000). For more detailed information about the sampled period, number of fish sampled by month, number of years, and number of fish sampled by sex, see the online spreadsheet on the website mentioned above. In short, the data are the length-at-age of Gulf corvina from the UGC. Age was estimated by counting the annual growth bands observed in the transverse section of the sagittal otoliths (for more details see esperada, los supuestos biológicos y el ajuste a los datos (Zhu et al. 2009). La inferencia y estimación de los parámetros y la precisión de estás estimaciones se basan únicamente en el ajuste del modelo. Otro enfoque para elegir el mejor modelo está basado en la teoría de información. Este enfoque ha sido recomendado como una alternativa más sólida en comparación con los enfoques tradicionales (Katsanevakis 2006). El criterio de información de Akaike (AIC por sus siglas en inglés) es el más común entre los enfoques de teoría de información (Katsanevakis 2006, Cruz-Vásquez et al. 2012).

Los estudios previos que han analizado el crecimiento de $C$. othonopterus han utilizado únicamente el MCVB (Román-Rodríguez 2000, Erisman et al. 2009, Erisman 2012). Por esa razón, el objetivo del presente estudio fue determinar los parámetros de crecimiento individual de la corvina golfina en el AGC usando el enfoque multimodelo, así como evaluar el uso de datos promedio y datos totales de la longitud a la edad para el cálculo de los parámetros de crecimiento.

\section{MATERIALES Y MÉTODOS}

\section{Obtención de datos}

Los datos se obtuvieron de la base de datos de CONABIO (SNIB-CONABIO; http://www.conabio.gob.mx/institucion/ cgi-bin/datos.cgi? Letras $=$ L $\&$ Numero $=298$ ), específicamente de la hoja de cálculo Datos ecológicos 4 (Román-Rodríguez 2000). Para información más detallada sobre el período de muestreo, la cantidad de peces muestreados por mes, el número de años y el sexo, se recomienda visitar la hoja de cálculo en la página de internet mencionada líneas arriba. En resumen, los datos son la longitud a la edad de corvina golfina del AGC. La edad se calculó contando las bandas de crecimiento anual observadas en la sección transversal de los otolitos (para más detalles también se puede consultar Gherard et al. 2013). Se midieron un total 473 ejemplares (243 machos, 211 hembras y 19 juveniles indiferenciados). Para obtener los parámetros de crecimiento se utilizó la longitud total de cada organismo a la edad determinada, así como el promedio de los datos. Los datos utilizados son los datos combinados de las capturas de la pesquería dirigida y de las capturas incidentales de otras pesquerías. La pesca dirigida captura organismos más grandes, incluyendo organismos que pueden ser más grandes que la longitud promedio a la edad. La pesca incidental captura peces de menor tamaño y posiblemente más pequeños que la longitud promedio a la edad (Gherard et al. 2013). También se usaron los datos promedio de la longitud a la edad publicados por CRIP (2005) y los datos de Román-Rodríguez (2000) presentados como retrocalculados (tabla 1) y que provienen de la misma base de datos entregados a CONABIO. De aquí en adelante, los datos analizados se denominan base de datos 1 (CRIP 2005), base de datos 2 (Román Rodríguez 2000), base de datos 3 (datos promedio de CONABIO) y base de datos 4 (datos totales de 
Table 1. Average total length at different estimated ages. The number and standard deviation of analyzed specimens were only available for data set 3 .

Tabla 1. Longitud total promedio a diferentes edades estimadas. El número y la desviación estándar de las muestras analizadas sólo están disponibles para la base de datos 3 .

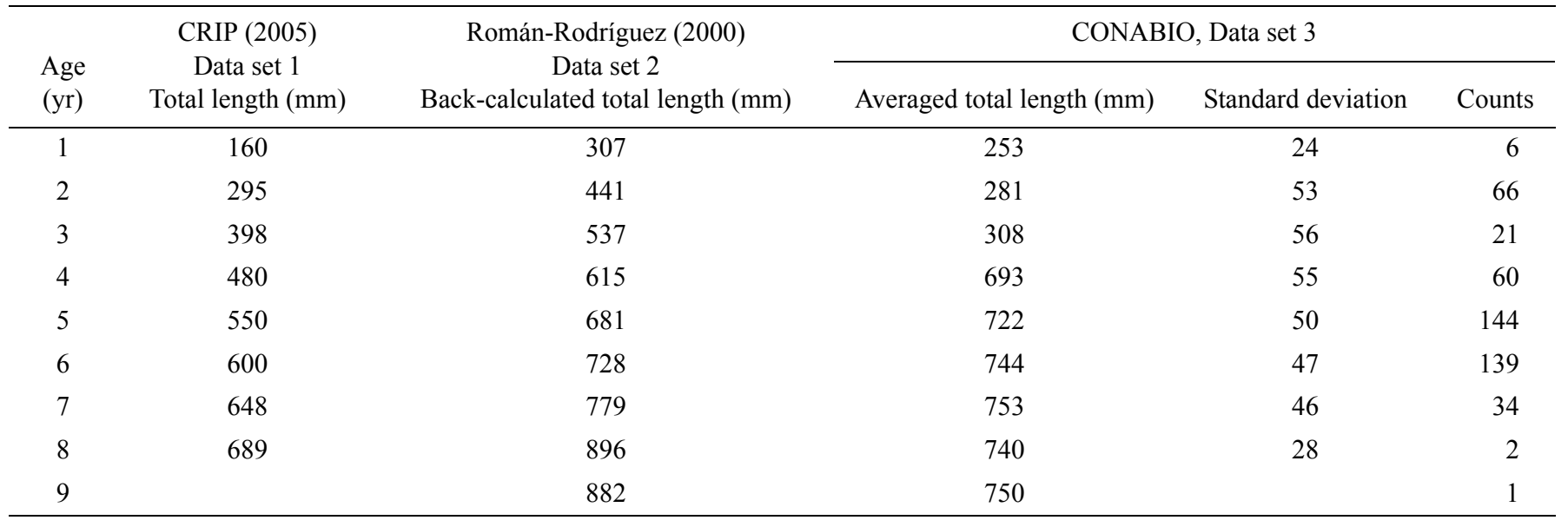

also Gherard et al. 2013). The total lengths of 473 individuals (243 male, 211 female, and 19 undifferentiated juveniles) that were measured and used to model Gulf corvina growth, as well as averages of these data, were obtained to model growth. The data used are the raw combined data from the directed fishery and from by-catch fisheries. The Gulf corvina fishery targets larger fish, including fish that may be larger than the average size at age, whereas the bycatch fisheries target smaller-sized fish and possibly those smaller than the average size at age (Gherard et al. 2013). Averaged length-at-age data published in CRIP (2005) were also used, as well as data reported by Román-Rodríguez (2000) as backcalculated (table 1) from the same data source delivered to the CONABIO data base as raw data. Hereafter, the analyzed data are called data set 1 (CRIP 2005), data set 2 (RománRodríguez 2000), data set 3 (averaged CONABIO data), and data set 4 (raw CONABIO data). To validate age determinations, Román-Rodríguez (2000) used the relationships between age and otolith weight, age and otolith radius, and length and otolith radius (for more details see also Gherard et al. 2013).

\section{Model selection and inference about individual growth}

An information theory approach was adopted to estimate individual growth parameters (Schnute and Groot 1992, Katsanevakis 2006, Katsanevakis and Maravelias 2008). Five asymptotic models (table 2) were chosen to address lengthat-age data and determine which model was best: VBGM, a logistic model (Ricker 1975), the Gompertz growth model, the Schnute model (Schnute 1981), and the Schnute-Richards growth model (Schnute and Richards 1990). These models were selected, among other alternatives, because they have been used to model fish growth.
CONABIO). Para validar las determinaciones de edad, Román Rodríguez (2000) utilizó las relaciones entre edad y peso de los otolitos, edad y radio de los otolitos, así como longitud y radio de los otolitos (para más detalles véase también Gherard et al. 2013).

\section{Selección del mejor modelo y la inferencia del crecimiento individual}

Se usó un enfoque de teoría de la información para estimar los parámetros de crecimiento individual (Schnute y Groot 1992, Katsanevakis 2006, Katsanevakis y Maravelias 2008). Se eligieron cinco modelos asintóticos (tabla 2) para ajustarlos a los datos de longitud a la edad y establecer cuál modelo representaba mejor el patrón de crecimiento de corvina golfina: el MCVB, el modelo de crecimiento de Gompertz, un modelo logístico (Ricker 1975), el modelo de Schnute (Schnute 1981) y el modelo de Schnute-Richards (Schnute y Richards 1990). Estos modelos fueron seleccionados, entre otras alternativas, porque han sido utilizados para modelar el crecimiento de peces.

Para calcular la longitud asintótica $\left(L_{\infty}\right)$ con el modelo de Schnute, es necesario utilizar la siguiente ecuación:

$$
L_{\infty}=\left[\frac{e^{\lambda \tau_{2} \delta \rho}-e^{\lambda \tau_{1} 1 \rho}}{e^{\lambda \tau_{2}}-e^{\lambda \tau_{1}}}\right]^{\frac{1}{\rho}}
$$

Los modelos fueron ajustados usando el criterio de máxima verosimilitud según la siguiente ecuación:

$$
L L(\Phi \mid \text { datos })=-\left(\frac{n}{2}\right)(\operatorname{Ln}(2 \pi)+2 * \operatorname{Ln}(\sigma)+1)
$$


Table 2. Growth models confronted to Gulf corvina, Cynoscion othonopterus, from the Upper Gulf of California.

Tabla 2. Modelos de crecimiento confrontados para corvina golfina, Cynoscion othonopterus, del Alto Golfo de California.

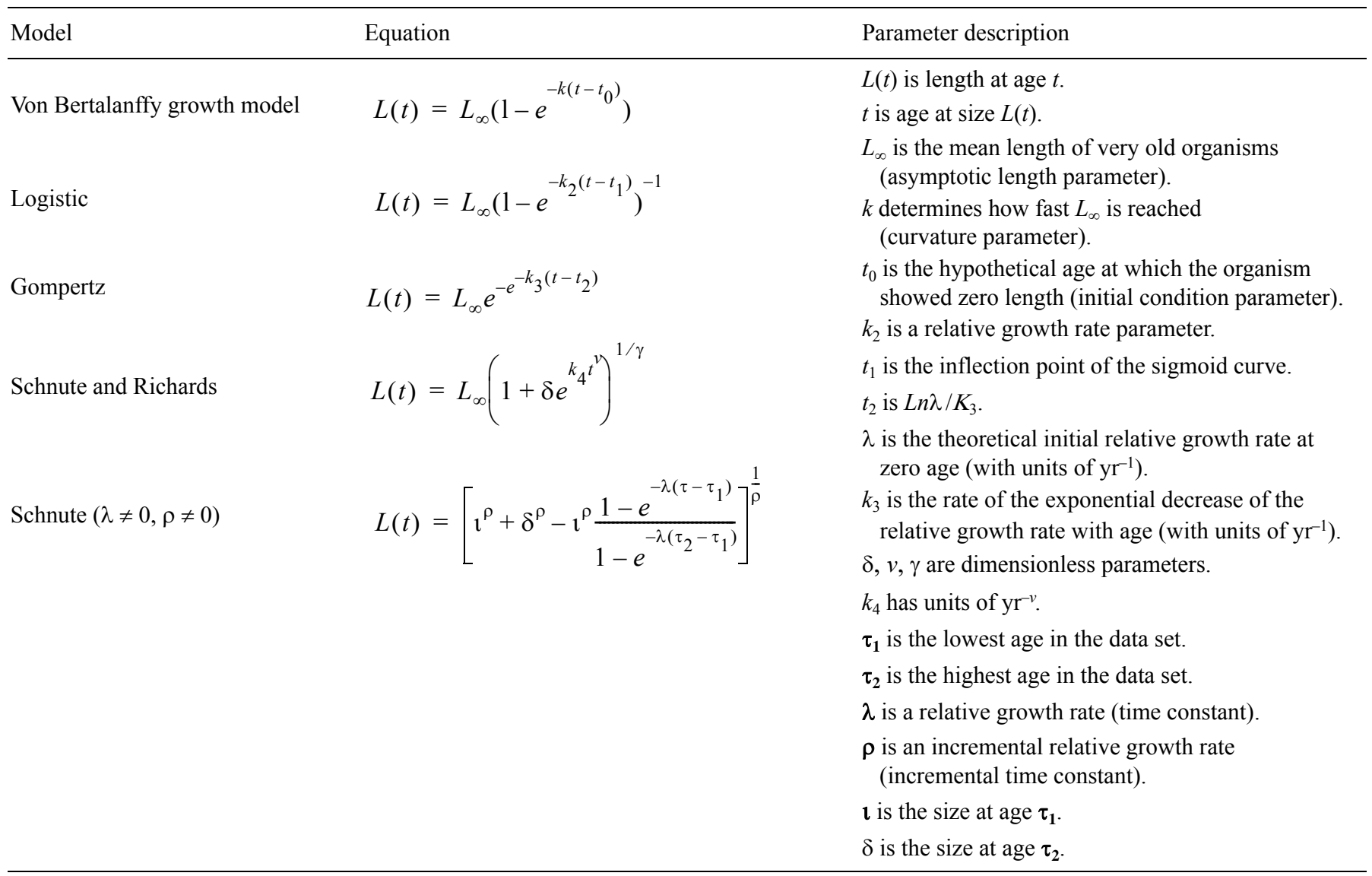

To compute the asymptotic length $\left(L_{\infty}\right)$ with the Schnute model, it is necessary to use the following equation:

$$
L_{\infty}=\left[\frac{e^{\lambda \tau_{2} \delta \rho}-e^{\lambda \tau_{1} l \rho}}{e^{\lambda \tau_{2}}-e^{\lambda \tau_{1}}}\right]^{\frac{1}{\rho}}
$$

The models were fitted using maximum likelihood based on the following equation:

$$
L L(\Phi \mid \text { datos })=-\left(\frac{n}{2}\right)(\operatorname{Ln}(2 \pi)+2 * \operatorname{Ln}(\sigma)+1)
$$

where $L L$ is the negative log-likelihood, $\Phi$ represents the parameters of the models, and $\sigma$ represents the standard deviations of the errors, calculated using the following equation:

$$
\sigma=\sqrt{\sum \frac{\left(L_{o b s}-\hat{L}\right)^{2}}{n}}
$$

donde $L L$ es la máxima verosimilitud logarítmica negativa, $\Phi$ representa los parámetros de los modelos y $\sigma$ representa la desviación estándar y fue calculada usando la siguiente ecuación:

$$
\sigma=\sqrt{\sum \frac{\left(L_{o b s}-\hat{L}\right)^{2}}{n}}
$$

La selección del modelo se llevó a cabo a través de una forma corregida del AIC $\left(\mathrm{AIC}_{\mathrm{c}}\right.$ ) (Shono 2000, Burnham y Anderson 2002). El modelo con el menor valor de $\mathrm{AIC}_{\mathrm{c}}$ fue seleccionado como el mejor.

$$
A I C_{c}=A I C+\frac{2 k(k+1)}{n-k-1}
$$

y

$$
A I C=2 L L+2 k
$$

donde $n$ es el número de observaciones y $k$ es el número de parámetros en el modelo. 
Model selection was performed using the bias-corrected form of the AIC $\left(\mathrm{AIC}_{\mathrm{c}}\right.$ ) (Shono 2000, Burnham and Anderson 2002). The model with the lowest $\mathrm{AIC}_{\mathrm{c}}$ value was chosen as the best model.

$$
A I C_{c}=A I C+\frac{2 k(k+1)}{n-k-1}
$$

and

$$
A I C=2 L L+2 k
$$

where $n$ is the number of observations, and $k$ is the number of parameters in each model.

For all models, the $\Delta_{i}$ values were calculated as the differences between the $\mathrm{AIC}_{\mathrm{c}}$ of each model $\left(A I C_{i}\right)$ and the $\mathrm{AIC}_{\mathrm{c}}$ with the lowest value $\left(A I C_{\text {min }}\right)$ :

$$
\Delta_{i}=A I C_{i}-A I C_{\text {min }}
$$

The plausibility of each model (the weight of evidence for model $i$ ) was estimated using the following formula for the Akaike weight $\left(w_{i}\right)$ :

$$
w_{i}=\frac{e\left(-0.5 \Delta_{i}\right)}{\sum_{k=1}^{5} e\left(-0.5 \Delta_{k}\right)}
$$

Following a multi-model inference approach, the "average" $L_{\infty}\left(\bar{L}_{\infty}\right)$ was calculated as the sum of the product of the $L_{\infty}$ parameters multiplied by the corresponding $w_{i}$ for all acceptable models as follows:

$$
\bar{L}_{\infty}=\sum_{i=1}^{5} w_{i} \hat{L}_{\infty, i}
$$

The $95 \%$ confidence intervals were estimated for each candidate model using the following equation:

$$
\hat{L}_{\infty}= \pm t_{\text {d.f., }, 0.975} \operatorname{SE}\left(\hat{L}_{\infty}\right)
$$

where

$$
\operatorname{SE}\left(\bar{L}_{\infty}\right)=\sum_{i=1}^{5} w_{i}\left(\operatorname{var}\left(\hat{L}_{\infty, i} \mid g_{i}\right)+\left(\hat{L}_{\infty, i}-\bar{L}_{\infty}\right)^{2}\right)^{1 / 2}
$$

where $\operatorname{var}\left(\hat{L}_{\infty, i} \mid g_{i}\right)$ is the variance of the estimated asymptotic length according to model $g_{i}$, conditional on the model.
Para todos los modelos, se calcularon los valores de $\Delta_{i}$ como las diferencias entre los $\mathrm{AIC}_{\mathrm{c}}$ de cada modelo $\left(A I C_{i}\right) \mathrm{y}$ el $\mathrm{AIC}_{\mathrm{c}}$ con el menor valor $\left(A I C_{\text {min }}\right)$, según la siguiente ecuación:

$$
\Delta_{i}=A I C_{i}-A I C_{\min }
$$

Para cada modelo, se calculó la plausibilidad (el peso de la evidencia a favor del modelo $i$ ) a través de la ponderación del criterio de información Akaike $\left(w_{i}\right)$ como se describe a continuación:

$$
w_{i}=\frac{e\left(-0.5 \Delta_{i}\right)}{\sum_{k=1}^{5} e\left(-0.5 \Delta_{k}\right)}
$$

Siguiendo el enfoque de la inferencia multimodelo, se determinó la $L_{\infty}$ "promedio" $\left(\bar{L}_{\infty}\right)$ como la suma del producto de $L_{\infty}$ multiplicada por su correspondiente $w_{i}$ para todos los modelos candidatos aceptados, según la siguiente ecuación:

$$
\bar{L}_{\infty}=\sum_{i=1}^{5} w_{i} \hat{L}_{\infty, i}
$$

Se calculó el intervalo de confianza al $95 \%$ de cada $L_{\infty}$ para cada modelo candidato:

$$
\hat{L}_{\infty}= \pm t_{\text {d.f., }, 0.975} \operatorname{SE}\left(\hat{L}_{\infty}\right)
$$

donde:

$$
\operatorname{SE}\left(\bar{L}_{\infty}\right)=\sum_{i=1}^{5} w_{i}\left(\operatorname{var}\left(\hat{L}_{\infty, i} \mid g_{i}\right)+\left(\hat{L}_{\infty, i}-\bar{L}_{\infty}\right)^{2}\right)^{1 / 2}
$$

donde var $\left(\left(\hat{L}_{\infty, i} \mid g_{i}\right)\right.$ es la varianza de la longitud asintótica estimada según modelo $g_{i}$, condicionada al modelo.

\section{RESULTADOS}

La longitud total (LT) varió de 145 a $920 \mathrm{~mm}$, con un promedio de $635.2 \pm 16.7 \mathrm{~mm}$ y una moda de $710 \mathrm{~mm}$ (fig. 2). La distribución bimodal resultó de la combinación de los datos de la captura incidental y los datos provenientes de la pesca dirigida. La edad estimada de los peces osciló entre 1 y 9 años (tabla 1). Los peces de mayor edad midieron $750 \mathrm{~mm}$ TL. Los individuos más jóvenes midieron $252.5 \pm 23.8 \mathrm{~mm}$ LT. El individuo más pequeño (145 mm LT) tenía 2 años de edad, y el pez más grande (920 mm LT) tenía 6 años. 


\section{RESULTS}

The total length (TL) ranged from 145 to $920 \mathrm{~mm}$, averaging $635.2 \pm 16.7 \mathrm{~mm}$ with a mode of $710 \mathrm{~mm}$ (fig. 2). A bimodal distribution resulted from the combination of the bycatch and targeted fisheries data. The estimated age of the fishes ranged from 1 to 9 years (table 1). The oldest individuals measured $750 \mathrm{~mm}$ TL. The youngest individuals had a TL of $252.5 \pm 23.8 \mathrm{~mm}$ on average. The smallest individual collected (145 mm TL) was 2 years old. The largest fish (920 mm TL) was 6 years old.

For each model and data set, table 3 shows the corresponding AIC, $\Delta_{i}, w_{i}, L_{\infty}$, SE and $95 \%$ confidence limits of $L_{\infty}$, and the averaged $L_{\infty}$ with its SE and confidence limits. According to the AIC value, the VBGM was selected as the best model for data sets 1 and 2, whereas the Schnute-Richards model was selected as the best for data sets 3 and 4 . The criterion proposed by Burnham and Anderson (2002) is that models with $\Delta_{i}>10$ are not supported by the data and should not be considered for parameter estimation. The analysis of data sets 1,3 , and 4 produced $\Delta_{i}$ values higher than 10 for the rest of the models tested and were not selected as the best. Only for data set 2 were there four models with $\Delta_{i}<10$. The Schnute-Richards model produced the smallest value $\left(L_{\infty}=735.0 \mathrm{~mm}\right)$ for data set 4 as well as the largest value $\left(L_{\infty}=2007.8 \mathrm{~mm}\right)$ for data set 2 .

In general, the five models yielded highly divergent asymptotic lengths for each data set. Figure 3 shows this finding more clearly, but in figure $3(a, b)$ the curves were arbitrarily extended to an age of $20 \mathrm{yr}$ to accentuate the differences among the curves. If the curves are limited to the actual data used, the differences between the growth curves are difficult to detect for data sets 1 and 2, but all of the growth curves are clearly distinguishable for data sets 3 and 4 (fig. 3c, d). The growth parameters for C. othonopterus from

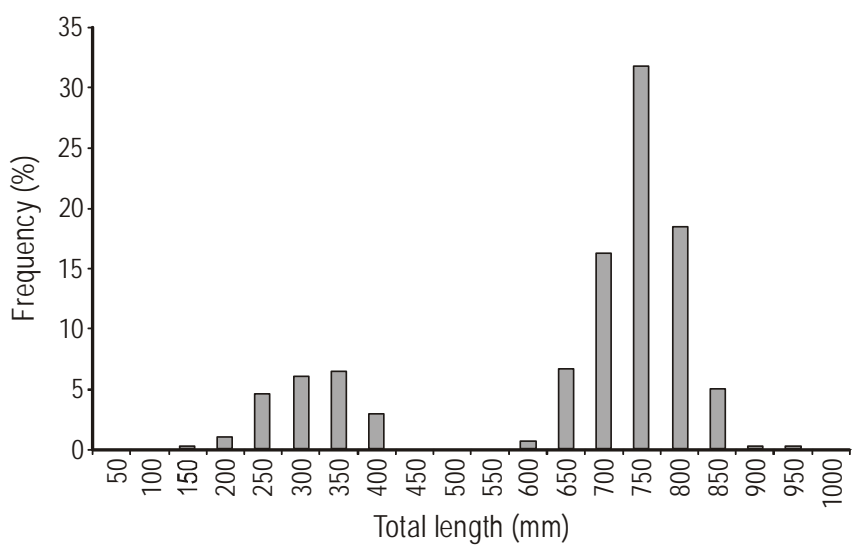

Figure 2. Length frequency distributions of Cynoscion othonopterus from the Upper Gulf of California.

Figura 2. Distribución de frecuencias de longitud de Cynoscion othonopterus del Alto Golfo de California.
Para cada modelo y base de datos, en la tabla 3 se presenta el valor correspondiente de $\mathrm{AIC}, \Delta_{i}, w_{i}, L_{\infty}$, error estándar e intervalo de confianza al $95 \%$ para cada $L_{\infty}$; también se presenta el valor promedio de $L_{\infty}$ con su respectivo error estándar y sus límites de confianza. Según los valores de AIC, el MCVB fue seleccionado como el modelo que mejor representó la base de datos 1 y 2 , mientras que para las bases de datos 3 y 4 el modelo de Schnute-Richards fue seleccionado como el mejor modelo. Burnham y Anderson (2002) propusieron que el modelo con $\Delta_{i}>10$ no está suficientemente soportado por los datos y, por tanto, no debería ser considerado en la estimación de parámetros. Al analizar las bases de datos 1,3 y 4 , se produjeron valores de $\Delta_{i}$ mucho mayores que 10 para el resto de modelos que no fueron seleccionados como el mejor. Solamente en la base de datos 2 se encontró que cuatro modelos presentaron valores de $\Delta_{i}<10$. El modelo de Schnute-Richards estimó el menor valor de longitud asintótica $\left(L_{\infty}=735.0 \mathrm{~mm}\right)$ con la base de datos $4 \mathrm{y}$ el mayor valor de longitud asintótica $\left(L_{\infty}=2007.8 \mathrm{~mm}\right)$ con la base de datos 2 .

En general, los cinco modelos produjeron longitudes asintóticas altamente variables para cada base de datos. La figura 3 muestra este hallazgo más claramente, pero en las figuras 3(a, b), las curvas se extendieron arbitrariamente hasta una edad de 20 años para poder realzar las diferencias entre las curvas. Si las curvas se limitan nada más a los datos observados (1 a 9 años), las diferencias entre las curvas de crecimiento son difíciles de detectar con las bases de datos 1 y 2, pero todas las curvas de crecimiento son claramente distinguibles con las bases de datos de 3 y 4 (fig. 3c, d). Los parámetros de crecimiento de $C$. othonopterus del AGC calculado con el MCVB y la comparación con similares resultados de estudios anteriores se muestran en la tabla 4 .

\section{DiscUSIÓN}

Los estudios previos sobre el crecimiento de corvina golfina (C. othonopterus) sólo han ajustado el MCVB sin probar modelos alternativos. En el presente estudio se ajustaron cinco modelos a datos de longitud a la edad de esta especie del AGC. De las alternativas usadas en el presente estudio, se encontró que un patrón de crecimiento bifásico es el mejor para describir el crecimiento de la especie.

Un patrón de crecimiento bifásico puede ser producto de la edad reproductiva, y esto se debe considerar al momento de ajustar modelos de crecimiento (Ohnishi et al. 2012). Gherard et al. (2013) encontraron que un cambio en la distribución de energía ocurre en la corvina golfina después de una edad de dos años debido a la maduración y el inicio de la reproducción. Estos resultados apoyan el patrón de crecimiento bifásico encontrado en el presente estudio. Un modelo de crecimiento bifásico ha sido obtenido por la unión de dos versiones independientes del MCVB a una edad arbitraria para poder generar una curva de crecimiento (Ohnishi 
Table 3. Number of parameters used in each model $(K)$, Akaike information criterion (AIC), Akaike differences $\left(\Delta_{i}\right)$, Akaike weights $\left(w_{i}\right)$, estimated asymptotic length $\left(L_{\infty}\right)$, and the corresponding conditional asymptotic standard error (SE) and $95 \%$ conditional confidence limits (CL) for each candidate model (VBGM, von Bertalanffy growth model). The model-averaged $L_{\infty}$, SE, and $95 \%$ confidence limits are also given.

Tabla 3. Cantidad de parámetros usados en cada modelo $(K)$, Criterio de Información de Akaike (AIC), diferencias de Akaike $\left(\Delta_{i}\right)$, ponderación de Akaike $\left(w_{i}\right)$, longitud asintótica estimada $\left(L_{\infty}\right)$ y su correspondiente error estándar (SE) y límites de confianza al $95 \%$ para cada modelo (VBGM, modelo de crecimiento de von Bertalanffy). También se muestran los promedios de $L_{\infty}$ con su respectivo error estándar y los límites de confianza

\begin{tabular}{|c|c|c|c|c|c|c|c|c|}
\hline Model & $K$ & AIC & $\Delta_{i}$ & $w_{i}(\%)$ & \multicolumn{4}{|c|}{$L_{\infty}(\mathrm{mm})$} \\
\hline \multicolumn{9}{|l|}{ Data set 1} \\
\hline VBGM & 3 & 50 & 0 & 99.98 & 837.6 & 0.93 & 835.5 & 839.6 \\
\hline Schnute and Richards & 5 & 68 & 18 & 0.02 & 1095.4 & 0.49 & 1094.3 & 1096.5 \\
\hline Schnute & 4 & 86 & 36 & 0.00 & 890.5 & 0.36 & 889.7 & 891.3 \\
\hline Logistic & 3 & 173 & 123 & 0.00 & 699.1 & 3.39 & 691.8 & 706.4 \\
\hline Averaged $L_{\infty}$ & & & & & 837.6 & 0.97 & 835.5 & 839.7 \\
\hline \multicolumn{9}{|l|}{ Data set 2} \\
\hline VBGM & 3 & 90 & 0 & 62.21 & 1175.8 & 6.56 & 1161.6 & 1189.9 \\
\hline Gompertz & 3 & 92 & 2 & 24.42 & 1025.9 & 7.28 & 1010.2 & 1041.7 \\
\hline Averaged $L_{\infty}$ & & & & & 1126.6 & 80.57 & 955.8 & 1297.4 \\
\hline \multicolumn{9}{|l|}{ Data set 3} \\
\hline Schnute and Richards & 5 & 97 & 0 & 99.62 & 741.2 & 3.41 & 733.7 & 748.7 \\
\hline Schnute & 4 & 110 & 13 & 0.16 & 750.2 & 13.54 & 720.7 & 779.7 \\
\hline Logistic & 3 & 110 & 13 & 0.14 & 778.3 & 20.48 & 734.0 & 822.5 \\
\hline Gompertz & 3 & 113 & 15 & 0.05 & 805.9 & 23.02 & 756.2 & 855.7 \\
\hline VBGM & 3 & 115 & 17 & 0.02 & 913.8 & 26.05 & 857.5 & 970.1 \\
\hline Averaged $L_{\infty}$ & & & & & 741.3 & 3.55 & 733.8 & 748.8 \\
\hline \multicolumn{9}{|l|}{ Data set 4} \\
\hline
\end{tabular}

the UGC computed with VBGM and the comparison with similar results from previous studies are shown in table 4 .

\section{Discussion}

Previous studies on Gulf corvina (C. othonopterus) growth have fitted the VBGM without examining alternative models. In the present study, five growth models were fitted to age and growth data for this species from the UGC. Among the alternatives used here, a biphasic growth pattern was found to best describe the growth of this species. et al. 2012). En otras palabras, el MCVB fue modificado con el propósito de ajustar un patrón de crecimiento bifásico en peces (Tribuzio et al. 2010, Ohnishi et al. 2012). En el presente estudio se encontró que la corvina golfina presenta un patrón de crecimiento bifásico, que sólo fue identificado al usar el modelo con el mayor número de parámetros, el modelo de Schnute-Richards. Tribuzio et al. (2010) encontraron que el AIC siempre optaba por la versión bifásica del MCVB sobre la versión monofásica del mismo MCVB en un estudio de crecimiento del cazón espinoso común. En el presente estudio, independientemente de si se usaban los datos 

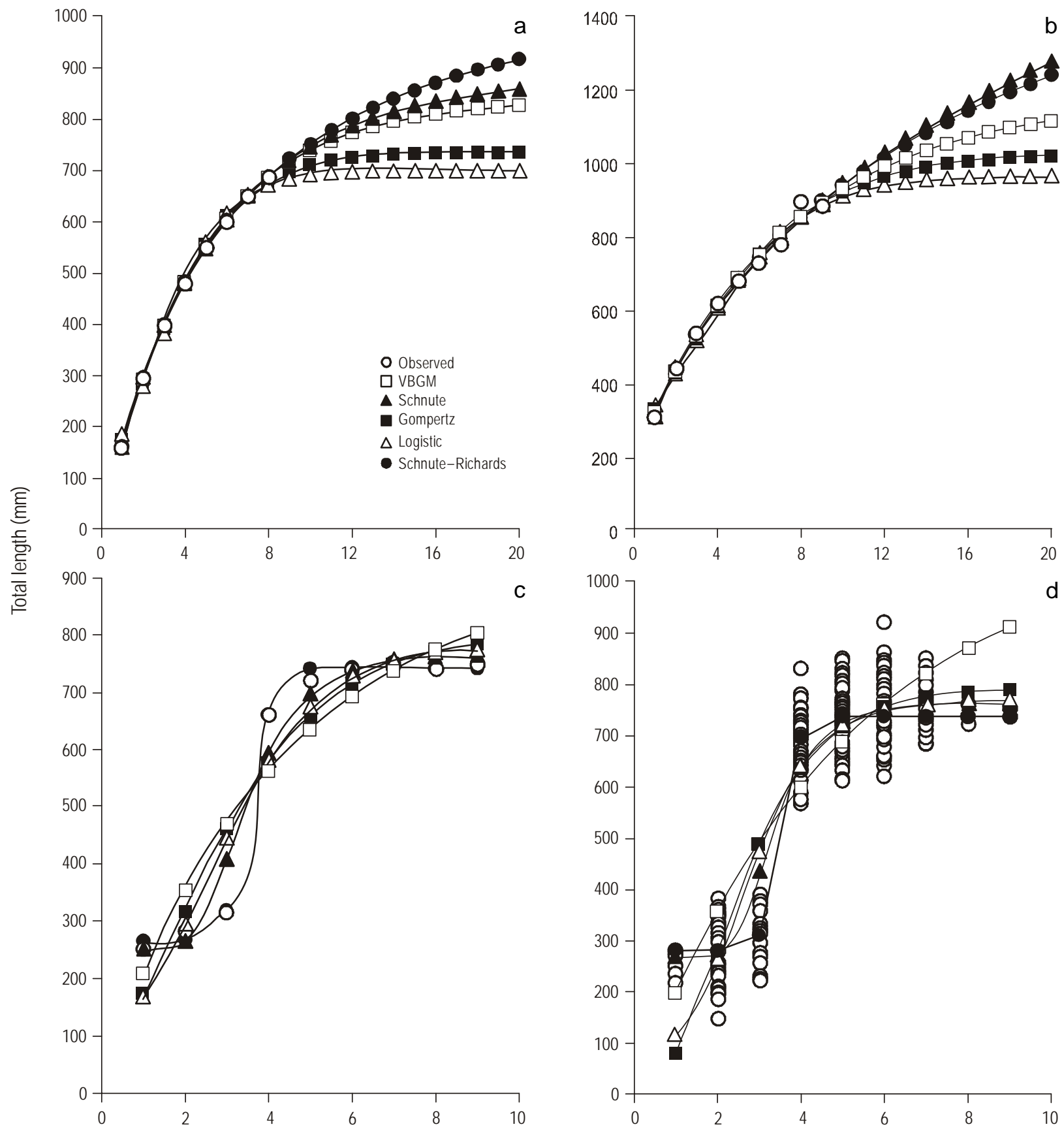

Age (years)

Figure 3. Growth curves generated by five models for each data set for Cynoscion othonopterus from the Upper Gulf of California. VBGM, von Bertalanffy growth model.

Figure 3. Curvas de crecimiento generadas por los cinco modelos para cada base de datos de Cynoscion othonopterus del Alto Golfo de California. VBGM, modelo de crecimiento de von Bertalanffy.

A biphasic growth pattern could be an effect of reproductive age, and this should be taken into account for fitting a growth model (Ohnishi et al. 2012). Gherard et al. (2013) found that a shift in energy allocation occurs in Gulf corvina after age two due to maturation and the onset of reproduction. These results support the biphasic growth pattern found in the totales o los datos promedio, el AIC seleccionó el modelo de Schnute-Richards, que presentó una curva bifásica en ambos casos (figs. 3, d). Esto es posible porque el modelo tiene la ventaja de que contiene la forma común del MCVB, incluyendo la función logística y el modelo de Gompertz como casos especiales. El modelo consiste en una ecuación 
Table 4. Estimated growth parameters of Cynoscion othonopterus using the von Bertalanffy growth model. $L_{\infty}$ is the asymptotic length, $k$ is the curvature parameter, and $t_{0}$ is the hypothetical age at which the organism showed zero length.

Tabla 4. Parámetros de crecimiento estimados para Cynoscion othonopterus usando en modelo de crecimiento de von Bertalanffy. $L_{\infty}$ es la longitud asintótica, $k$ es la curvatura del parámetro, y $t_{0}$ es la edad hipotética a la cual el orgamismo mostró una longitud de cero.

\begin{tabular}{lcccc}
\hline Source & $L_{\infty}$ & $k$ & $t_{0}$ & Reference \\
\hline Data set 1 & 837.55 & 0.212 & -0.012 & This study \\
Data set 2 & 1175.77 & 0.139 & -1.27 & This study \\
Data set 3 & 913.80 & 0.230 & -0.13 & This study \\
Data set 4 & 1099.66 & 0.195 & -0.0005 & This study \\
Least squared & 783 & 0.47 & Fixed 0 & Erisman (2012) \\
Least trimmed squares procedure & 763 & 0.52 & Fixed 0 & Erisman (2012) \\
Exploratory fits & Fixed 900 & 0.24 & Fixed 0 & Erisman (2012) \\
Exploratory fits & Fixed 1000 & 0.30 & Fixed 0 & Erisman (2012) \\
Exploratory fits & 789 & 0.44 & Fixed -0.2 & Erisman (2012) \\
Exploratory fits & 793 & 0.41 & 0.616 & Erisman (2012) \\
& 1006 & 0.255 & -18.96 & Gherard et al. (2013) \\
& 2940 & 0.00117 & 0.38 & Erisman et al. (2009) \\
\end{tabular}

present study. A biphasic growth model derived by connecting two independent VBGMs at an arbitrary age has been reported for curve fitting (Ohnishi et al. 2012). In other words, the VBGM has been modified as an approach to fitting a biphasic growth pattern in fishes (Tribuzio et al. 2010, Ohnishi et al. 2012). In the present study, we observed that the Gulf corvina exhibits a biphasic growth pattern, which was identified by the higher-parameter model used, the Schnute-Richards model. Tribuzio et al. (2010) found that the AIC always selects the biphasic VBGM over the monophasic VBGM in dogfish. In the present study, whether raw or averaged data were used, the AIC selected the Schnute-Richards model, and it displayed a biphasic curve in both cases (fig. $3 \mathrm{c}, \mathrm{d})$. This is possible because the model has the advantage of containing the common form of the VBGM, including the logistic function, and the Gompertz model as special cases. The model consists of a differential equation forming eight different curve patterns depending on the parameter values. The VBGM is a special case among the alternative solutions. The Schnute-Richards model is a general growth model that contains most of the other growth models as special cases. Rather than modeling the instantaneous rate of change, the model focuses on the relative rate of change. Additionally, the parameterization approach of the model is statistically stable.

Erisman (2012) stated that a biphasic growth model may be more applicable and appropriate for Gulf corvina, but neglected to use one because biphasic growth models have seen limited use and are difficult to apply to further fisheries analysis. Erisman (2012) used VBGM because the author considered it to be the standard for growth curves. As clearly shown by Ohnishi et al. (2012), if the objective is to describe the growth performance of a species, the best model must diferencial formando ocho patrones de curvas diferentes dependiendo de los valores del parámetro. El MCVB es un caso especial dentro de las soluciones alternativas. El modelo Schnute-Richards es un modelo de crecimiento general que contiene la mayoría de los otros modelos de crecimiento como casos especiales. En lugar de modelar la tasa instantánea de cambio, el modelo se centra en la velocidad relativa de cambio. Además, el enfoque de la parametrización del modelo es estadísticamente estable.

Erisman (2012) afirmó que un modelo de crecimiento bifásico puede ser más aplicable y apropiado para corvina golfina, pero se negó a usarlo porque los parámetros de los modelos de crecimiento bifásico son difíciles de aplicar para un posterior análisis en modelos pesqueros. Erisman (2012) usó el MCVB porque consideró que es el estándar para las curvas de crecimiento. Sin embargo, como fue demostrado por Ohnishi et al. (2012), si el objetivo es describir el patrón de crecimiento de una especie, debe usarse el mejor modelo que lo describa. Un patrón de crecimiento bifásico implica un retraso en el crecimiento debido a la redistribución de energía para los procesos reproductivos. Esto implica que por seguir un análisis pesquero, el conocimiento del desempeño biológico de las especies se ha perdido en los estudios de crecimiento.

Los datos usados en este estudio fueron los datos totales y datos promedio que se encuentran disponibles en la literatura. No fue posible seguir hasta su fuente original los datos de CRIP (2005), pero los datos de Román-Rodríguez (2000) son los datos estimados como retrocalculados y provienen de la misma base de datos analizados aquí como base de datos $3 \mathrm{y}$ 4 (banco de datos de CONABIO). La razón de comparar estas cuatro bases de datos fue motivada porque las relaciones de longitud a la edad en Román Rodríguez (2000) y CRIP 
be applied. A biphasic growth pattern implies a delay in growth due to the reallocation of energy to reproductive processes. This implies that by targeting a fishery analysis, the biological performance of a species is lost in growth studies.

The data used in this study were the raw data and averaged data available in the literature. It was not possible to trace the CRIP (2005) data to the source, but the RománRodríguez (2000) data are back-calculated from the same source (CONABIO data bank) analyzed here as data sets 3 and 4. The reason for comparing these four sets of data was because the length-at-age relationships in the CRIP (2005) and Román-Rodríguez (2000) data sets do not provide individual length-at-age variability but rather a probabilistic and aggregated evaluation of age for fishes of the same size. This might lead to important errors in the length-at-age estimated for individuals, as younger, fast-growing fishes are impossible to discriminate from older, slow-growing fishes of the same size. For this reason, in the present study, the comparisons were made with the hypothesis that cases 1 to 3 will identify the same model as the best and only case 4 will select a different model as the best. This study shows that regardless whether averaged or total raw data are used, the same biphasic growth pattern is described by the same model.

Another important issue is the source of data. Erisman (2012) assumed that bycatch fish are caught with different gear in different locations and that growth may be different for different sub-populations. This assumption is important because $C$. othonopterus has a very restricted geographic range, being endemic to the northern Gulf of California. Erisman (2012) concluded that separating the data from the corvine fishery produced a growth model that was significantly different from one that includes samples from both the fishery and bycatch samples, and recommended that conclusive age-growth relationships should be derived from fisheryindependent samples to minimize potential biases introduced by fishing behavior related to either the bycatch fishery or the targeted fishery (e.g., differences in mesh size, fishing location, and method of fishing - drift gill net versus encircling). Both demonstrate a high degree of selectivity that confers bias that may not accurately reflect the true corvina population.

For this study, it was assumed that juvenile Gulf corvina were landed as bycatch in the shrimp fishery during the autumn and winter months and that they were collected with different mesh size gear, but were still captured with a gillnet, as this is allowed for the shrimp fishery. It is clear that the smallest-sized individuals in figure 2 came from bycatch, but they were from the same population. In this study, a direct method to determine individual age based on counting growth bands was used. For this reason, a bias was not expected, as could occur when using an indirect approach such as size modal analysis to infer age.

After the American Fisheries Society listed $C$. othonopterus as a vulnerable species, a Corvina Working
(2005) no contemplan la variabilidad individual de longitud a la edad sino más bien una evaluación probabilística y agregada de edad para peces de la misma longitud. Esto podría conducir a errores importantes en la estimación de longitud a la edad de los individuos, lo cual hace difícil distinguir peces jóvenes de crecimiento rápido de los peces mayores de crecimiento lento del mismo tamaño. Por esta razón, en el presente estudio, las comparaciones se hicieron con la hipótesis de que en los casos de las bases de dato 1 a 3 se seleccionaría el mismo modelo como el mejor y en la base de datos 4 se seleccionaría un modelo diferente como el mejor. En este estudio, se encontró que aunque se usen los datos promedio o datos totales, el mismo patrón de crecimiento bifásico es descrito por el mismo modelo.

Otra cuestión importante es la fuente de datos. Erisman (2012) mencionó que los peces provenientes de la captura incidental fueron capturados con diferentes artes de pesca y en diferentes localidades; por tanto, el crecimiento debe ser diferente por pertenecer a diferentes subpoblaciones. Este supuesto es importante porque $C$. othonopterus tiene una distribución geográfica muy restringida, siendo endémica en el norte del Golfo de California. Erisman (2012) concluyó que al separar los datos de la pesca dirigida de corvina se produjo un modelo de crecimiento que fue significativamente diferente de aquel que incluyó muestras combinadas de la captura incidental y la captura dirigida. Recomendó que para obtener una irrefutable relación edad-crecimiento, el análisis debe hacerse con muestras independientes de la industria pesquera para minimizar los posibles sesgos introducidos por el comportamiento de la pesca incidental o la pesca dirigida (e.g., diferencias en la luz de malla, sitios pesqueros y métodos de pesca_redes agalleras de deriva vs redes de encierro). Ambas demuestran un alto grado de selectividad que confiere el sesgo que puede no representar con exactitud la verdadera estructura de la población de corvina.

En este estudio, se partió del supuesto de que los peces jóvenes de corvina golfina fueron desembarcados como captura incidental durante las faenas de pesca de camarón en los meses de otoño e invierno y recolectados con artes de pesca de diferente luz de malla al que utiliza la pesca dirigida. Sin embargo, los peces fueron capturados con la redes agalleras de deriva permitidas en la pesca de camarón. Es evidente que los individuos de tallas más pequeñas que se muestran en la figura 2 provienen de la pesca incidental, pero provienen de la misma población. En este estudio, se utilizó un método directo para determinar edad la individual basada en el recuento de bandas de crecimiento. Por esta razón, no esperamos un sesgo, como podría ocurrir cuando se usa un enfoque indirecto como análisis de progresión modal para inferir la edad.

Después de que la sociedad americana de pesquerías enlistó a $C$. othonopterus como una especie vulnerable, se formó un grupo técnico para el estudio de corvina golfina que presenta recomendaciones para el manejo pesquero de esta especie. Por esa razón, Erisman (2012) desarrolló un análisis 
Group was formed to give advice and recommendations for Gulf corvina fishery management. Erisman (2012) performed a virtual population analysis (VPA) and an evaluation of fishing management scenarios. A VPA is driven by estimates of life history parameters, such as von Bertalanffy growth parameters from growth studies. Consequently, Erisman (2012) tried many options (see table 4) for adjusting the asymptotic length and growth rate parameters of the VBGM. Many combinations were tried and, therefore, some results (such as $t_{0}=-18$ or $\mathrm{t}_{0}>0$ ) are considered unreliable according to the logic on which the growth models are based. In the present study, the focus was the growth pattern rather than adjustment of the VBGM logic parameters.

It is worth noting that data set 2 in the present study and Román-Rodríguez (2000) are the same data (tables 1, 4) but with dissimilar results. A possible explanation for this is that in previous reports, the growth parameters were estimated using an algorithm based on the ordinary least squares method. Consequently, using a likelihood ratio test instead (as done in this study) represents a better solution to adequately estimate the individual growth parameters (Katsanevakis 2006). This finding is important because for data set 2, the VBGM was selected as the best model using the AIC approach, but again with dissimilar results for the asymptotic length and growth rate parameters. This provides an opportunity to reassess much of the historical fisheries data that were estimated using an algorithm based on the ordinary least squares method.

In this study, the objective was to analyze the growth of Gulf corvina instead of just applying the VBGM. The conclusion is that the growth of $C$. othonopterus exhibits a biphasic pattern that is better described by a higher-parameter model such as the Schnute-Richards model.

\section{ACKNOWLEDGMENTS}

This study received financial support from the Mexican Council for Science and Technology (CONACYT, project 178727 CB-2012-1). The Mexican Council for Knowledge and Use of Biodiversity (CONABIO) allowed the use of their data bank (SNIB-CONABIO spreadsheet project L298).

\section{REFERENCES}

Acosta Valenzuela Y. 2010. Ecología reproductiva y potencial reproductivo de curvina golfina Cynoscion othonopterus (Jordan y Gilbert, 1882) en el alto golfo de California y delta del río Colorado. MSc Thesis, Instituto Tecnológico de Guaymas, Sonora, México, $122 \mathrm{pp}$.

Alp A, Kara C, Ückardes F, Carol J, García-Berthou E. 2011. Age and growth of the Europian catfish (Silurus glanis) in a Turkish reservoir and comparison with introduced populations. Rev. Fish Biol. Fish. 21: 283-294. http://dx.doi.org/10.1007/s11160-010-9168-4

Baer A, Schulz C, Traulsen I, Krieter J. 2011. Analysing the growth of turbot (Psetta maxima) in a commercial recirculation sytem with the use of three different growth models. Aquacult. Int. 19: 497-511. de población virtual (APV) y presentó diferentes escenarios de manejo pesquero. Un APV es manipulado por la estimación de los parámetros de historia de vida, como los parámetros de crecimiento individual que se generan en los estudios de crecimiento con el MCVB. En consecuencia, Erisman (2012) probó muchas opciones (véase la tabla 4) para ajustar la longitud asintótica y la tasa de crecimiento que se necesitan en el MCVB; este autor intentó muchas combinaciones, por lo que algunos resultados (como $t_{0}=-18 \mathrm{o}$ $\mathrm{t}_{0}>0$ ) son considerados poco confiables, según la lógica en que se basan los modelos de crecimiento. En el presente estudio, el objetivo fue determinar el patrón de crecimiento en lugar del simple ajuste de los parámetros de crecimiento según algún modelo.

Es necesario resaltar que la base de datos 2 del presente estudio y los datos presentados en Román-Rodríguez (2000) son los mismos datos (tablas 1 y 4), pero con resultados disímiles. Una posible explicación para esto es que RománRodríguez (2000) estimó los parámetros de crecimiento mediante un algoritmo basado en el método de mínimos cuadrados ordinarios. El uso del criterio de máxima verosimilitud en su lugar (como en este estudio) representa una mejor solución para estimar adecuadamente los parámetros de crecimiento individual (Katsanevakis 2006). Es importante tener esto en cuenta porque para la base de datos 2, el MCVB fue seleccionado como el mejor modelo utilizando el AIC, pero otra vez con resultados disímiles para los parámetros de tasa crecimiento y longitud asintótica. Esto proporciona una oportunidad para reconsiderar muchos de los datos históricos de pesca que se calcularon utilizando un algoritmo basado en el método de mínimos cuadrados ordinarios.

En este estudio, el objetivo fue analizar el crecimiento de corvina golfina en lugar de simplemente aplicar el MCVB. Se concluye que el crecimiento de C. othonopterus exhibe un patrón de crecimiento bifásico que es mejor descrito por un modelo con mayor cantidad de parámetros, como el de Schnute-Richards.

\section{Agradecimientos}

EAAN recibió financiamiento del Consejo Nacional de Ciencia y Tecnología (CONACYT, CB-2012-1 proyecto 178727). La Comisión Nacional para el Conocimiento y Uso de Biodiversidad (CONABIO) autorizó el uso de su banco de datos (hoja de cálculo SNIB-CONABIO proyecto No. L298).

Burnham KP, Anderson DR. 2002. Model Selection and Multimodel Inference: A Practical Information-theoretic Approach. Springer, New York, 488 pp.

Chao LN. 1995. Sciaenidae. Corvinas, barbiches, bombaches, corvinatas, corvinetas, corvinillas, lambes, pescadillas, roncachos, verrugatos. In: Fischer W, Krupp F, Schneider W, Sommer C, Carpenter KE, Niem V (eds.), Guia FAO para identificación de especies para los fines de la pesca. Pacifico centro-oriental. FAO, Roma, pp. 1427-1518. 
CRIP (Centro Regional de Investigaciones Pesqueras). 2005. Compilación biológico-pesquera de corvina golfina, Cynoscion othonopterus en el Alto Golfo de California. Technical Report: 1-12 (http://www.cofemermir.gob.mx/mir/uploadtests/ 7357.66.59.1.Compilacion\%20curvina.doc).

Cruz-Vásquez R, Rodríguez-Domínguez G, Alcántara-Razo E, Aragón-Noriega EA. 2012. Estimation of individual growth parameters of the Cortes Geoduck Panopea globosa from the central Gulf of California using a multimodel approach. J. Shellfish Res. 31: 725-732. http://dx.doi.org/10.2983/035.031.0316.

Erisman BE. 2012. Evaluation of available data, preliminary datapoor assessment and recommendations for the Gulf corvina fishery in the Gulf of California. Technical Report to the Environmental Defense Fund. EDF, La Jolla, California, 39 pp.

Erisman BE, Paredes G, Mascareñas-Osorio I, Aburto Oropeza O. 2009. Preliminary report on the Gulf corvina, Cynoscion othonopterus. Technical Report to NOS. Noroeste Sustentable, San Diego, California, 77 pp.

Erisman B, Aburto-Oropeza O, González-Abraham C, MascareñasOsorio I, Moreno-Baez M, Hastings PA. 2012. Spatio-temporal dynamics of a fish spawning aggregation and its fishery in the Gulf of California. Sci. Rep. 2, 284: 1-11. http://dx.doi.org/10.1038/srep00284

Gherard KE, Erisman BE, Aburto-Oropeza O, Rowell K, Allen LG. 2013. Growth, development, and reproduction in Gulf corvina (Cynoscion othonopterus). Bull. South. Calif. Acad. Sci. 112: $1-18$. http://dx.doi.org/10.3160/0038-3872-112.1.1

Hadj-Taieb A, Ghorbel M, Hadj-Hamida NB, Jarboui O. 2013. Sex ratio, reproduction, and growth of the gilthead sea bream, Sparus aurata (Pisces: Sparidae), in the Gulf of Gabes, Tunisia. Cienc. Mar. 39: 101-112. http://dx.doi.org/10.7773/cm.v39i1.2146

Katsanevakis S. 2006. Modelling fish growth: Model selection, multi-model inference and model selection uncertainty. Fish. Res. 81: 229-235.

Katsanevakis S, Maravelias D. 2008. Modelling fish growth: Multimodel inference as a better alternative to a priori using the von Bertalanffy equation. Fish Fish. 9: 178-187.

Ohnishi S, Yamakawa T, Okamura H, Akamine T. 2012. A note on the von Bertalanffy growth function concerning the allocation of surplus energy to reproduction. Fish. Bull. 110: 223-229.

Powers SP, Hightower CL, Drymon JM, Johnson MW. 2012. Age composition and distribution of red drum (Sciaenops ocellatus) in offshore waters of the north central Gulf of Mexico: An evaluation of a stock under a federal harvest moratorium. Fish. Bull. 110: 283-292.

Ricker WE. 1975. Computation and interpretation of biological statistics of fish populations. Fish. Res. Board Can. Bull. 191: $1-382$.

Rodríguez-Quiroz G, Aragón-Noriega EA, Valenzuela-Quiñónez W, Esparza-Leal HM. 2010. Artisanal fisheries in the conservation zones of the Upper Gulf of California. Rev. Biol. Mar. Ocean. 45: 89-98.

Román-Rodríguez MJ. 2000. Estudio poblacional del chano norteño Micropogonias megalops y la curvina golfina Cynoscion othonopterus (Gilbert) (Pisces: Sciaenidae), especies endémicas del Alto Golfo de California, México. Instituto del Medio Ambiente y Desarrollo Sustentable del Estado de Sonora. Hoja de cálculo SNIB-CONABIO proyecto No. L298. CONABIO, México, $143 \mathrm{pp}$.

Rowell K, Flessa KW, Dettman DL, Román M. 2005. The importance of Colorado River flow to nursery habitats of the Gulf corvina (Cynoscion othonopterus). Can. J. Fish. Aquat. Sci. 62: 2874-2885.

Rowell K, Flessa KW, Dettman DL, Román M, Gerber LR, Findley LT. 2008. Diverting the Colorado River leads to a dramatic life history shift in an endangered marine fish. Biol. Conserv. 131: $1138-1148$.

Sadovy Y, Erisman B. 2012. Fishery and biological implications of fishing spawning aggregations, and the social and economic importance of aggregating fishes. In: Sadovy YJ, Colin PL (eds.), Reef Fish Spawning Aggregations: Biology, Research, and Management. Springer, pp. 225-284. http://dx.doi.org/10.1007/978-94-007-1980-4_8

Schnute J. 1981. A versatile growth model with statistically stable parameters. Can. J. Fish. Aquat. Sci. 38: 1128-1140.

Schnute J, Groot K. 1992. Statistical analysis of animal orientation data. Anim. Behav. 43: 15-33.

Schnute J, Richards LJ. 1990. A unified approach to the analysis of fish growth, maturity, and survivorship data. Can. J. Fish. Aquat. Sci. 47: 24-40.

Shono H. 2000. Efficiency of the finite correction of Akaike's information criteria. Fish. Sci. 66: 608-610.

Tribuzio CA, Kruse GH, Fujioka JT. 2010. Age and growth of spiny dogfish (Squalus acanthias) in the Gulf of Alaska: Analysis of alternative growth models. Fish. Bull. 108: 119-135.

Zhu L, Li L, Liang Z. 2009. Comparison of six statistical approaches in the selection of appropriate fish growth models. Chin. J. Oceanol. Limnol. 27: 457-467.

Received February 2014, accepted May 2014 